\title{
WAS THE UNITED KINGDOM'S POLICY OF PUSHING FOR THE RETURN OF ROHINGYA REFUGEES TO MYANMAR FOLLOWING ETHNIC CLEANSING IN 2017 REALISTIC?
}

\begin{abstract}
This article explores the United Kingdom's response to the Rohingya Crisis which began in August 2017, resulting in the ethnic cleansing of 600,000 Rohingya Muslims in the first nine weeks of violence, with a minimum of 6,700 people being killed in the process. The United Kingdom reacted with condemnation, and began immediately calling for the safe return of refugees who had fled the violence, to their homes in Rakhine state, Myanmar. Using the testimony from Mark Field MP, Minister for Asia, in a Foreign Affairs Committee meeting, this essay assesses this policy of pushing for the return of the Rohingya to their homes. Using primary sources available to Britain at the time its policy was formed, this essay argues that Britain's approach was not only unrealistic with regards to providing an environment in which Rohingya refugees would be provided safety, but also in relation to Burmese authorities' desires to take back Rohingya refugees. Myanmar's campaign of ethnic cleansing intentionally created the environment in which either the Rohingya would never return, or they would return to state-controlled concentration camps. Secondary material expires the history of violent state policies against the Rohingya in Myanmar, and Britain's policy is shown to not only be unworkable due to such policies, but would actively endanger those refugees who chose to return.

Key words: Rohingya; Myanmar; Britain; ethnic nationalism; genocide; ethnic eleansing; foreign policy
\end{abstract}

ARTHUR J. HOLMES University of St Andrews, St Andrews E-mail: arthurholmes96@gmail.com https://orcid.org/0000-0002-3661-3971

CITATION: Holmes, A.J. (2019). Was the United Kingdom's policy of pushing for the return of Rohingya refugees to Myanmar following ethnic cleansing in 2017 realistic? Sprawy Narodowościowe. Seria nowa, 2019(51). https://doi.org/10.11649/sn.1800

This work was supported by the author's own resources. No competing interests have been declared.

This is an Open Access article distributed under the terms of the Creative Commons Attribution 3.0 PL License (creativecommons.org/licenses/by/3.0/pl/), which permits redistribution, commercial and non-commercial, provided that the article is properly cited. (C) The Author(s) 2019

Publisher: Institute of Slavic Studies, Polish Academy of Sciences 


\section{CZY POLITYKA WIELKIEJ BRYTANII W KWESTII POWROTU UCHODŹCÓW ROHINGIA DO BIRMY PO CZYSTKACH ETNICZNYCH W 2007 ROKU BYtA REALISTYCZNA?}

\section{Streszczenie}

Artykuł omawia kryzys, który rozpoczą się w sierpniu 2017 roku i spowodował czystki etniczne obejmujące około 600000 muzułmanów z ludu Rohingya, przy czym w pierwszych 9 tygodniach gwattownych zamieszek śmierć poniosło co najmniej 6700 osób. Zjednoczone Królestwo potępiło czystki i natychmiast wezwało do umożliwienia uchodźcom bezpiecznego powrotu do ich domów w Birmie. Na podstawie wyjaśnień ministra ds. Azji Marka Fielda, członka parlamentu, Komitet ds. Spraw Zagranicznych na swym posiedzeniu dokonał oceny tej polityki, polegającej na nakłanianiu ich do powrotu do Birmy. Opierając się na źródłach dostępnych w Wielkiej Brytanii w chwili, gdy tworzyły się zręby tej polityki, autor eseju dowodzi, że ten kierunek polityczny był nie tylko nierealistyczny w odniesieniu do możliwości zapewnienia uchodźcom bezpieczeństwa, ale także sprzeczny z zamiarami władz Birmy w kwestii przyjęcia uchodźców. Burmańska kampania czystek etnicznych świadomie stworzyła sytuację, w której Rohingya nigdy nie powrócą bądź wracaliby do kontrolowanych przez państwo obozów koncentracyjnych. Dostępne opracowania analizują historię przemocy wobec ludności Rohingya w Birmie i ukazują politykę Wielkiej Brytanii nie tylko jako nieskuteczną z powodu takich posunięć politycznych, ale także wskazują, że zagrażałaby ona życiu decydujących się na powrót uchodźców. [Przet. Jacek Serwański]

Stowa kluczowe: Rohingya; Birma; Wielka Brytania; nacjonalizm etniczny; ludobójstwo; czystka etniczna; polityka zagraniczna

In August 2017, an attack on Burmese border guards by the Arakan Rohingya Salvation Army (ARSA) was met with what the Myanmar (Burmese) government described as 'clearance operations' in Rakhine state. This campaign entailed brutal attacks on Myanmar's minority ethnolinguistic Muslim population in Rakhine-the Rohingya. ${ }^{1}$ At least 6,700 people were killed and over 600,000 Rohingya fled across the Naf river into neighbouring Bangladesh in the first nine weeks (Foreign Affairs Committee, 2017, Q71). This campaign included mass killings, rapes, mutilations and the razing of hundreds of villages formerly occupied by the Rohingya minority. The 'crackdown' as described by the Myanmar military was alternatively defined by the United Nations (UN) as ethnic cleansing, and a leading voice in condemning this campaign was the United Kingdom ("UN human rights chief points to 'textbook example of ethnic cleansing' in Myanmar", 2017). ${ }^{2}$ The UK, a permanent member of the UN Security Council (UNSC) and former colonial ruler in Myanmar, had close ties to Burmese history and the plight of the Rohingya. This essay will assess Britain's response to the ethnic cleansing which was most explicitly outlined in a Foreign Affairs Committee meeting, in which the British government voiced its desire for the voluntary, internationally observed return of the Rohingya to Bangladesh (Foreign Affairs Committee, 2017, Q69).

\section{-.....}

The term 'Rohingya' has become politicised and contested by the Myanmar authorities, who deny the Rohingya rights to citizenship and have even denied their existence as an ethnic group. The Rohingya are clearly identifiable by their language, which has Indo-European roots, opposed to the official Sino-Tibetan language of Myanmar. They have been persecuted more than other minorities in Myanmar mainly as a result of their Islamic faith.

2 Myanmar's military is split between the political National Defence and Security Council (NDSC) and the armed forces, or 'Tatmadaw'. 
A number of issues need to be addressed to allow this essay to precisely critique Britain's policy. Firstly, the term 'realistic' will refer to not only the plausibility of this policy being implemented in Myanmar, but also the plausibility of it being done in a way which ensured a secure and dignified future for the Rohingya-one which the Rohingya themselves were likely to accept. Britain made it clear in outlining its policy that these were its priorities, and by utilising historical analysis of the Rohingya's situation in Myanmar alongside an examination of what the August 2017 ethnic cleansing entailed, an informed conclusion can be made. Secondly, violence against the Rohingya is ongoing at the time of writing, yet this essay will refer only to events and sources which existed prior to the 23rd November 2017 Myanmar-Bangladesh agreement on repatriation. The bilateral agreement was described as an essential step in solving the Rohingya crisis, and this date ensures that only primary material available to policymakers at the time is used to assess their decisions.

Secondary source material on this topic is relatively limited, and further historical inquiry into Myanmar's treatment of the Rohingya needs to be undertaken. That being said, years of reports by journalists and a handful of academic papers on life in Myanmar for the Rohingya prior to August 2017 can be used to shed light on how they had been subjected to a decades-long campaign of state-level stigmatisation, persecution and violence before ethnic cleansing began. Issues regarding domestic politics in Bangladesh, ARSA insurgency, human trafficking of refugees and the potential application of the terms 'apartheid' and 'genocide' all add to the discussion on Rakhine, yet this essay will focus purely upon Britain's approach to the crisis as an episode of ethnic cleansing. ${ }^{3}$

Evidence provided in this essay shall show that the chances of Rohingya voluntarily returning, or even being allowed to return to Myanmar, were minimal, if not non-existent. It will show Britain's policy to have been unrealistic. How and why Britain came to form this policy will be explored, before the perspective of Burmese authorities is explained in order to highlight the flaws in Britain's approach. Opinion on repatriation from the Rohingya perspective is also analysed in oder to give a voice to the Rohingya themselves-something British policy seemingly ignored.

Myanmar continued to the time of writing to deny access to international investigators and humanitarian organisations, yet consistent stories and reports flowed out of Rakhine state from the moment this phase violence started in August 2017. It is this evidence that shall be used to judge whether or not Britain's policy was realistic.

\section{BRITAIN'S APPROACH: REPATRIATING REFUGEES}

During an inquiry by the UK's Foreign Affairs Committee (FAC), Mark Field MP, British Minister of State for Asia and the Pacific, spelled out the government's approach to the violence in Rakhine state (Foreign Affairs Committee, 2017). This meeting was the clearest voicing of UK policy, and acts as an invaluable source for showing what solution to the crisis Britain desired. Their policy was to push for the return of Rohingya refugees through a bilateral (Myanmar-Bangladesh) agreement alongside international observation and UN human rights access. This was intended to create an environment in which the Rohingya could feel secure, but also add international expertise on the ground to help both Rohingya and participating authorities (Foreign Affairs Committee, 2017, Q73).

\footnotetext{
3 The most comprehensive overview of the historic and current political and humanitarian situations in which the Rohingya find themselves can be found in Ibrahim, 2018.
} 
The term 'repatriation' is itself problematic. Philippe Ther in his 2015 work The Dark Side of Nation States highlighted how refugee repatriation has historically been synonymous to ethnic cleansing, defined by the UN as:

a purposeful policy designed by one ethnic or religious group to remove by violent and terrorinspiring means the civilian population of another ethnic or religious group from certain geographic areas (Ther, 2016, p. 2; "Definitions: Ethnic cleansing", n.d.).

Ethnic cleansing has been widely applied to Myanmar's violent campaign in Rakhine state, but the term could also be applied if the Rohingya were to be forcibly returned to Myanmar from Bangladesh's refugee camp in Cox's Bazar. ${ }^{4}$ As Ther argues, 'population transfer' is euphemistic for ethnic cleansing when the UN definition is applied, as its literal meaning is to forcibly remove a group from a given area. In order to avoid this, Britain made it clear that all repatriation should be voluntary and that the Rohingya themselves should be allowed to choose whether or not to return. This avoided the possibility of a new, internationally backed phase of ethnic cleansing occurring as a result, but itself created underlying issues which made the application of Britain's policy questionable.

It must also be noted that in Field's evidence to the FAC he hinted at other policy options at the UK's disposal. Threat of International Criminal Court (ICC) involvement was described as part of Britain's "diplomatic armoury" (Foreign Affairs Committee, 2017, Q76). Mr Field however made the bemusing claim that if refugees did indeed return, then discussions on ethnic cleansing or crimes against humanity as prosecutable crimes wouId "disappear into the background" (Foreign Affairs Committee, 2017, Q73). Britain saw the return of refugees as a goal which, if achieved, would mean prosecution or other policy options could be forgotten. This is because Britain's policy is fundamentally a diplomatic compromise. In making this compromise, the Foreign \& Commonwealth Office (FCO) aimed for a quick fix to the Rohingya question, repatriating refugees before they could forget about the 2017 affair as soon as possible. Their goal was to avoid escalation which could have forced the government's hand in the direction of intervention, if it was that Myanmar's actions were accepted as crimes against humanity or genocide (Foreign Affairs Committee, 2017, Q81). ${ }^{5}$ Unlike in other crises such as Sierra Leone in 2000, Afghanistan in 2001 or Iraq in 2003, Britain had no wider interests in the security of Myanmar or indeed the Rohingya in Rakhine state, and so repatriation was seen as a sufficient fix. ${ }^{6}$ Britain had no real interest in escalating the perceived severity in the plight of the Rohingya, even if victims themselves wanted justice. Clearly, the British government did not believe it had a moral obligation to punish those guilty of the most horrific crimes. It was thus unsurprising that the government was happy to ignore any discussions on international crimes once ethnic cleansing began in August 2017.

Mr Field justified Britain's approach by saying that if refugees did not return, the Myanmar military would be seen to have "won" (Foreign Affairs Committee, 2017, Q123). In other words, if new homes in safer states away from Myanmar were found for the Rohingya, then the Burmese authorities could see this as a successful campaign with Rakhine state having been 'cleansed'. On the surface, this approach could make sense with regards to avoiding future maltreatment of minorities, but in reality Mr Field was implying -...

4 UN application of 'ethnic cleansing' term in 'Army offensive aimed at preventing return of Rohingya' ("Army offensive aimed at preventing return of Rohingya", 2017); Population transfer in Ther, 2016, p. 2.

5 States have an obligation to take action in cases of genocide under the 1948 Genocide Convention.

6 Wider interests include securing oil, mineral or other economic incentives with intervention. Intervention or further action against Myanmar would be purely on humanitarian grounds, whereas the Sierra Leone, Afghanistan and Iraq examples all also included additional incentives. 
that denying the Myanmar authorities victory was more significant than forming a policy which would help the Rohingya people. Given this argument, the remaining options for the UK government were thus to either make the refugee camps of Cox's Bazar permanent, or push for the return of 600,000 people to what may have remained of their homes in Myanmar. As Mr Field also made it clear in the FAC hearing that refugee camps should never be made permanent, repatriation became the British government's goal early on (Foreign Affairs Committee, 2017, Q117). This approach had the added benefit to the British government of removing the question of rehousing Rohingya Muslims abroadan option undoubtedly deemed politically undesirable for a right of centre party in the Islamophobic political climate of the UK and wider political West. ${ }^{7}$ It would have been a struggle for Britain to negotiate the granting of refugee status to the Rohingya in other states, without agreeing to accept many people themselves.

Britain's approach was ultimately aimed at a return to the status quo, one in which any persecution of Rohingya was kept within Burmese borders. ${ }^{8}$ Mr Field not only showed a lack of desire on the part of the government to help the Rohingya people in the form of safe, permanent residency, but also all but ignored the crimes of the authorities in Myanmar. In addition, the British government ignored the underlying, long-term issues faced by the Rohingya at the hands of the Burmese government which made repatriation undesirable for the Rohingya themselves, and was advised against by human rights groups. ${ }^{9}$ The UK's policy was formed with the experience of Rohingya Muslims in Myanmar as a sideline issue.

\section{THE ROHINGYA: LIFE IN MYANMAR}

Britain's approach to forming a response to the Myanmar crisis evidently had fundamental flaws from the outset. Their decision was to push for the creation of an environment in which Rohingya would want to return. This voluntary aspect of policy was a necessity, but itself causes great issues with how realistic a policy this is. In no way does this mean that the Rohingya are to blame for this difficulty, but instead that the UK should have taken more seriously the Rohingya's experience in the decades preceding August 2017.

The history of the Rohingya is understudied, complex and highly politicised. According to the Rohingya, Rakhine state has been their home for centuries (Galache, 2014, p. 2). ${ }^{10}$ On the contrary, ethnically Burmese Rakhine citizens and the Burmese government argue that the Rohingya settled in Myanmar from Bengal during Britain's colonisation of South Asia and have been illegally migrating into Myanmar since it gained independence in 1947 (Galache, 2014, p. 2; Ibrahim, 2018). Such debates have been ongoing since Myanmar's independence, and disputes over the identity of fleeing people disrupted Myanmar-Bangladesh bilateral talks as early as 1978 (Anand, 1978, p. 1000). It appears that the truth lies somewhere in between, and Carlos Sardiña Galache argues that simultaneously many Rohingya have historic roots in the region and many also crossed

\section{......}

Britain's recent history has seen a trend of anti-immigration and anti-refugee stances, particularly with regards to Muslim refugees (Sloan, 2017).

8 Persecution had been documented frequently since 1948, with peaks in 1978, the early 1990s and 2012 (Anand, 1978, pp. 1100-1101).

9 Amnesty International and other human rights groups warned about what the Rohingya would be returning to ("Myanmar: Rohingya returns unthinkable until apartheid structure is dismantled", 2017).

10 The history of the Rohingya is covered in the initial chapters of Ibrahim, 2018. 
during the colonial period (Galache, 2014, p. 11). In addition, Galache refutes the very idea that nationality should be framed in the way it is under Burmese law, that being that groups are defined by residency before the colonial period. Identity defined in this way should be applied to borders drawn after independence, especially given the amount of demographic changes which occur under imperialism (Galache, 2014, p. 4). This way of framing race and ethnicity in Myanmar is regarded as a hangover from British institutionalisation of such ideas during its time as coloniser (Galache, 2014, p. 4).

Because of this racialised dynamic, it is perhaps unsurprising that both sides have exaggerated their versions of the Rohingya story, but it is the Burmese Buddhist majority which has translated their version into violent, state-run policy. That being said, there exists a low-level of Islamic insurgency in Myanmar to which the Rohingya have been linked, though this is closely related to state persecution against Rohingya Muslims since 1982 (Ibrahim, 2018, p. 51). On some level at least, Myanmar's operations were aiming to remove Islamist insurgency completely, and this is what Burmese authorities used to justify their actions (Asrar, 2017b). Even so, Nikki Hayley, United States Ambassador to the UN, amongst others have highlighted that Myanmar's actions went far and beyond 'counterinsurgency', and so applying this as an explanation for ethnic cleansing is not appropriate (Haley, 2017). Myanmar's narrative of counterinsurgency thus had the twofold flaw of being completely disproportionate as a response to violence, and also such violence being a direct consequence of their own inhumane government policy.

Until 1982, the Burmese government had in fact recognised the Rohingya as an ethnic minority, before the autocratic ruling military restructured the state's approach toward minority groups (Green et al., 2015, p. 7). This was the institutionalisation of the scapegoating of the Rohingya, as they were then blamed for the existence of rifts between conflicting minority groups in Myanmar (Galache, 2014). ${ }^{11}$ Evidently, the rift between Burmese society and the Rohingya is vast, and not only are they stigmatised by the ethnically Burmese majority, but also by other minority groups in Myanmar-singled out by their unique circumstance of being neither linguistically Burmese nor religiously Buddhist. In 2014, Maung Zarni and Alice Cowley concluded that Myanmar had undergone a "slow-burning state-led process of deliberate destruction of the Rohingya as a population since 1978", suggesting that the 1982 laws were a part of an ongoing, long-term campaign against the Rohingya which has filtered down into everyday society (Zarni \& Cowley, 2014, p. 751). ${ }^{12}$ This in part explains other groups' involvement in violence over a number of decades, as well as their significant role in the ethnic cleansing campaign which began in August 2017.

Queen Mary, University of London's (QMUL) International State Crime Initiative (ISCI) published Countdown to Annihilation in 2015, which utilised research such as that by Zarni and Cowley to forewarn of these divisions and the potential for violent consequences, adding to on-the-ground research conducted by the ISCl themselves (Green et al., 2015). In their research, ISCl applied Daniel Feierstein's stages of genocide from his work Genocide as a Social Practice (Feierstein, 2014). ISCl adapted Feierstein's work into six stages which they argued can be used to show that a 'genocidal process' was taking place in Myanmar (Green et al., 2015, p. 23). In their conclusion, Penny Green et al. argue that Myanmar had followed four of the first six stages of genocide to the letter up to 2015 (Green et al., 2015, p. 99). This meant that Burmese authorities had stigmatised, harassed, isolated and syste-

1 Rakhine can refer to either the state, or the ethnicity of the state's majority population.

12 Genocide was also forewarned by the Association of Southeast Asian Nations (ASEAN) in 2015 (Ibrahim, 2018, p. 125). 
matically weakened the Rohingya population over a number of years, with the final two stages predicted to be genocide and "symbolic enactment" (Green et al., 2015, p. 99). ${ }^{13}$ As early as 1993, William McGowan linked Burmese treatment of Rohingya to ethnic cleansing in Yugoslavia, showing how institutionalised anti-Rohingya violence had existed in Myanmar for decades prior to 2017 (McGowan, 1993, p. 47). Persecution was institutionalised with the 1982 laws, but was subsequently implemented in decades worth of policies designed to make life for the Rohingya people unbearable.

This violent campaign came to a head with violence described by the $\mathrm{ISCl}$ as "Myanmar's Kristallnacht" (Green et al., 2015, p. 74). In 2012, Buddhist civilians were bussed to Rohingya villages and sections of cities so they could beat, rape and kill Rohingya Muslims en masse (Green et al., 2015, p. 74). ${ }^{14}$ The violence resulted in some Rohingya being forced into camps, separated from ethnoreligious Rakhine people and tightly controlled by Burmese security forces (Green et al., 2015, p. 80). Following isolation, the next step in Feierstein's process, along alarmingly similar lines to the stages adopted by Nazi Germany during the Holocaust, was predicted to be genocide.

Myanmar's Kristallnacht in part explains why 400,000 refugees were already residing in Cox's Bazar before August 2017. Not only was there increased organised violence in 2012, but a low level of violence of Rohingya was carried out over a number of years-shown by numerous, corroborating documentaries (such as those by the BBC's Newsnight and Al Jazeera News) (Myanmar: Are crimes against humanity taking place?, 2017; The hidden genocide, 2013). In addition, the ISCI's research highlights how the 2012 violence was a bureaucratically coordinated action which achieved its aim of forcing Rohingya into isolated zones within cities, and 'internal refugee camps' (or more simply, concentration camps) outside them (Green et al., 2015, p. 82). ${ }^{15}$ Such camps and the ethnoreligious segregation they imposed were revealed by Al Jazeera World in a documentary in August 2017-sixteen days before ethnic cleansing began in Rakhine state (Hindawi, Kishk, \& Grace, 2017).

The August 2017 campaign was thus not a short term issue for policymakers to consider. Britain's policy of pushing for voluntary repatriation suggested that the conditions needed to be right to allow for Rohingya to return. However, given the decades of persecution and weakening of the Rohingya minority in independent postcolonial Myanmar, saying that they would be returning to an "insecure situation", as Field put it, was an understatement of the largest degree (Foreign Affairs Committee, 2017, Q76). The British government provided no means by which the stigmatisation and state-sponsored segregation of Rohingya within Myanmar itself could be overcome. It appears that, given the severity of Myanmar's treatment of Rohingya, British policymakers were relying upon a combination of desperation and nostalgia on the part of the Rohingya to take themselves back across the border. Once more, it appears that Britain pushed for a return to the status quo-a situation where persecution may be ongoing but not impacting other states. What they barely considered, however, was that the Rohingya would be returning to a status quo designed at least to separate Rohingya in what Amnesty International amongst others have referred to as apartheid, and at most annihilate them altogether as the ISCl had warned in 2014 ("Myanmar: Rohingya trapped in dehumanising apartheid regime", 2017). Britain's policy also ignored the fact that violence in August was not simply

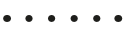

13 "Symbolic enactment" is described to entail the removal of the victim group from societal memory.

14 Burmese and Rakhine civilians are distinguishable by their albeit closely related languages, yet both profess Buddhism.

15 Refugee camps discussed in Ibrahim, 2018, p. 89. 
carried out by Burmese authorities, but also by civilians-the Rohingya's former neighbours. The picture of Britain's policy as unrealistic thus begins to crystallise.

\section{MYANMAR: ACCEPTING BACK AN UNWANTED PEOPLE?}

Over a number of decades, Myanmar carried out the state-sponsored stigmatisation and isolation of Rohingya, culminating in the 2017 ethnic cleansing and accompanying mass murder and systematic rape. Myanmar stripped Rohingya of citizenship rights and removed their identification papers in order to prevent them from working, freely moving, gaining education, accessing healthcare and more (Hindawi et al., 2017, 11:00). From a state level, Burmese authorities sought to separate, demonise and vilify the Rohingya community, resulting in a popular belief that the Rohingya deserve the violence which they received (Ibrahim, 2018, p. 14).

Violence against Rohingya was, and remains, a policy supported nationwide by a range of minority groups alongside the Buddhist majority and ruling government (Hindawi et al., 2017, 03:40). ${ }^{16}$ Removing Rohingya from Myanmar was a popular policy, which is reflected in part by Rakhine citizens' involvement in violence against Rohingya. Local Rakhine people looted houses, razed villages, raped women and killed adults and children both before and during Myanmar's 2017 ethnic cleansing (Green et al., 2015, p. 74). These actions were not just a consequence of Myanmar's government policy, but a constituent part of it. Burmese authorities have consistently shown that they do not want the Rohingya in their country, and so have actively encouraged violence on the part of both security forces and Burmese citizens in order to induce fear into Rohingya communities and force them to leave.

Alison Ruby Reid-Cunningham has argued that rape (such as that carried out during the 2017 ethnic cleansing campaign) is used in genocidal acts to symbolise the domination of an aggressor culture over their victims (Reid-Cunningham, 2008, p. 281). ${ }^{17}$ ReidCunningham writes that rape "represents a conquest of the woman by the rapist and, by symbolic extension, dominance of the raping culture over the raped culture" (ReidCunningham, 2008, p. 293). ${ }^{18}$ In this case, the propaganda fed to Burmese people from the Myanmar government and prominent Buddhist figures over a number of decades led to a paranoia amongst Burmese Buddhists that Muslims were 'taking over', and that Islam was synonymous to terrorism (Hindawi et al., 2017, 17:30). ${ }^{19}$ In violence against the Rohingya prior to 2017, rape became a frequent method of choice, symbolising the domination of Buddhism over Islam-fighting back against the 'invading terrorists' ${ }^{20}$ In August 2017, this tactic was implemented on a genocidal scale, with Burmese troops and local Buddhists joining in on the mass rape and sexual mutilation of Rohingya women and girls. Stories describing these acts were consistent from day one of the August

\footnotetext{
16 Burmese human rights protesters deny knowledge of abuse against Rohingya.

17 Reid-Cunningham uses the examples of Bosnia-Herzegovina (1992-1996), Rwanda (1994) and Darfur, Sudan (2003-present).

18 On the individual level, the rapist asserts "monarch-like power" over the victim, which translates to ethnic domination when rape is carried out on a genocidal scale; see Winkler, 1991, p. 12.

19 Terrorism does exist in Myanmar, albeit on a small scale, yet is likely to rise with the continued persecution and resulting desperation of Rohingya peoples (Ibrahim, 2018, p. 125).

20 The idea of Islam taking over fits the narrative of some strands of militant Buddhism which aims for security through the elimination of other religions, and Buddhist Monks in Myanmar have been leading voices in the persecution of the Rohingya (Ibrahim, 2018, p. 3.
} 
2017 campaign, with rape being intentionally utilised by Burmese authorities to symbolise of their power over the Rohingya. As Catherine A. Mackinnon writes, "sexually destroying the women of [a group] in these ways destroys the group" (Mackinnon, 2005, p. 338). Rape thus became a method for destroying the Rohingya without the need to exterminate them completely. Indeed, genocidal rape leaves surviving group members both physically and psychologically destroyed-rendering them powerless (Mackinnon, 2005, p. 338).

Further to this, in spite of hundreds of thousands of consistent stories the Burmese authorities denied the violence in Rakhine state once it began in August 2017. Aung San Suu Kyi, de jure leader and the West's nominated flag-bearer of democracy in Myanmar, rejected stories of rape and claims of ethnic cleansing from the outset, instead stating that there existed "a huge iceberg of misinformation" and lies from "terrorists" in Rakhine state. ${ }^{21}$ This was a mere extension of the previous denial of Rohingya's existencedenial that violence against them had occurred at all. Azeem Ibrahim has argued that Suu Kyi's background made this denial unsurprising, as Suu Kyi represents a ruling class in Myanmar which has zero sympathy for historic Rohingya strife (Ibrahim, 2018, p. 139). Indeed, as early as 1978 Myanmar was claiming that those fleeing Rakhine to Bangladesh were illegal 'Bengali immigrants' returning home (Anand, 1978, p. 1000). This undermined the first Myanmar-Bangladesh bilateral agreement of 1992, as Bangladesh also denied responsibility for Rohingya refugees fleeing violence, meaning the Rohingya were stateless with neither side accepting them as their own citizens (Anand, 1978, p. 1000). In addition, although Myanmar has been 'transitioning' to democracy since 2008, the pro -democracy half of government has deep familial links to the formerly autocratic military (Ibrahim, 2018, p. 139). Suu Kyi herself came from a family whose members were at the very top of independent Burmese politics, meaning she is more intertwined with the power-sharing military than many of her supporters in the West would like to believe (lbrahim, 2018, p. 139).

That being said, Aung San Suu Kyi's half of the government has been said to have had a minimal role in the 2017 violence itself, with observers including the British government placing the blame on the political National Defence and Security Council (NDSC) and Tatmadaw. ${ }^{22}$ Britain saw a complete removal of the military from power as a step toward securing rights for the Rohingya minority. However, in the case of the ethnic cleansing Suu Kyi was culpable and, as Ibrahim suggests, is as guilty allowing the persecution of the Rohingya to continue as the NDSC (Ibrahim, 2018, p. 139). Suu Kyi denied the violence was ongoing, and though the military implemented out the policy, Suu Kyi's evasion of specificity on the topic of violence in Rakhine renders her complicit-especially when considering her refusal to publicly condemn the Tatmadaw's actions and at times denying them altogether. This is a result of her complicity in the continuation of state-sponsored violence against the Rohingya, which intensified rather than subsided once the shift to democracy began (Ibrahim, 2018, p. 79). On September 19th 2017, Suu Kyi stated that she condemned "all human rights abuses", yet indiscreetly referenced villages that remained intact, rather than those which had been destroyed (Myanmar: Suu Kyi's first national speech on crisis, 2017). Suu Kyi's use of the terms "fake news" and "misinformation" countered the idea that the Burmese military attacked the Rohingya, and reenforced

\footnotetext{
21 Safi, M. 'Aung San Suu Kyi claims 'terrorists' are misinforming world about Myanmar violence', The Guardian, 6 September 2017; Ibrahim discusses the West's obsession with identifiable political heroes and villains, instead arguing that Suu Kyi's position is far less glamorous and more nuanced (Ibrahim, 2018, p. 2).

22 Ibrahim offers an excellent overview on the history of the Myanmar government (Ibrahim, 2018, pp. 17-53).
} 



Figure 1. Satellite image comparison: Tula Toli then and now. (Source: The Guardian/Ancestry)

claims made by security services that the Rohingya burned their own villages and killed their own people ("Rohingya Crisis: Suu Kyi says 'fake news helping terrorists'", 2017).

A further dynamic in this case is that under Burmese law, once a house has been razed, the ground on which it stood becomes government property (Lewis, 2017). This means that the razing of villages had the two-fold effect of removing the Rohingya themselves and legally giving their property to the state. Figure 1 is taken from a selection of satellite images widely distributed by human rights groups in September 2017, showing that the world knew of the razing of Rohingya villages from the start of the campaign of ethnic cleansing. Images of the village of Tula Toli epitomise what occurred across Rakhine state from August 25th 2017, as the homes of Rohingya Muslims were completely destroyed and their inhabitants either massacred, raped or forced to flee. Burmese housing law suggests that Myanmar saw the razing of villages as the best way to remove the remaining Rohingya from relatively 'free' areas and villages, forcing them into either newly controlled camps in Rakhine state or across the Naf river to neighbouring Bangladesh. When combined with the decades of human rights destruction for Rohingya, the systematic campaign which began in August appears to have been calculated to lead to one of these two situations. For Myanmar, they now had the ability to go into bilateral talks with the mindset that it does not matter whether the Rohingya return or not. Either they stay abroad and are someone else's problem, or they return to new concentration camps in which they can be easily controlled by authorities. The UN raised this issue in 2017, stating that Myanmar's actions were designed to prevent the return of the Rohingya (United Nations Human Rights Office of the High Commissioner, 2017).

The final point in this regard is that none of the previous repatriation agreements have solved the Rohingya crisis. Agreements between Myanmar and Bangladesh have been signed in the past but their impact has been minimal. Britain's focus on bilateral talks avoids tackling the issues surrounding repatriation, ensuring instead that they are not accused of interfering in other states' affairs. Given the success rate (or lack thereof) of pre- 
vious bilateral agreements, Britain's policy with regard to shifting the attitude of Burmese authorities is not a realistic one. Rather than simply sit back and wait for an agreement, Britain would have needed to see evidence of changes to previous agreements on repatriation in order for it to be successful. This was a blatantly obvious issue given previous failures, yet Britain made a choice not to tackle the problem. One man, Mohammad Yussuf, was repatriated in 1993 under one such agreement, yet ended up fleeing once more due to restrictions on citizenship rights ("Rohingya refugees in Bangladesh fear repatriation to Myanmar", 2017, 01:55). "My heart cries and asks why I can't go home", Yussuf said, saying that the Myanmar government had taken away his freedom ("Rohingya refugees in Bangladesh fear repatriation to Myanmar", 2017, 01:55). Myanmar may have taken back some Rohingya following past agreements, but the situation once they returned was as grave if not worse than when they left. Britain never considered these issues thoroughly enough, instead pushing an unrealistic solution which would put the Rohingya back under the control of a state whose politics is designed to persecute them.

Given the approach of Myanmar toward their Rohingya population, Britain's hopes of repatriating refugees were not realistic. For this to happen, Burmese authorities would have needed a complete ideological shift away from one of decades of discrimination and outright denial of Rohingya existence and right to reside, and also provide them with new securities and rights which allow them to lead free lives. There was never any evidence of a shift. By the time of the November agreement the military still controlled Rakhine state, and authorities were legal possession of the former lands of the Rohingya. Myanmar made it impossible for them to return to their homes, and were indifferent as to whether they remained in Cox's Bazar or return to new concentration camps in Rakhine. In either case, the Rohingya would be non-existent or systematically weakened to the extent that the Myanmar authorities controlled them entirely. Britain never addressed these issues, meaning their policy was totally unrealistic.

\section{THE ROHINGYA EXPERIENCE OF ETHNIC CLEANSING}

Finally, what must be considered and has remained absent in Britain's policy was the opinion of the Rohingya themselves. Myanmar's policy developments resulted in one of the most violent episodes of ethnic cleansing since the term was first defined by the United Nations in 1994 ("Definitions: Ethnic cleansing", n.d.). The British government did mention the severity of the violence when laying out their policy intentions, yet appeared to ignore what this meant for the individual Rohingya people who had experienced violence first hand, and how this would influence their own intentions to return home. ${ }^{23}$ Britain did not consider that some Rohingya could not bare to return to Myanmar following their experience of ethnic cleansing.

Attacks on Rohingya were described by victims as being perpetrated by the military in conjunction with the local non-Muslim population, whether that be the Burmese majority or other ethnolinguistic groups. The violence Rohingya experienced was some of the worst imaginable, and it is obvious that the perpetrators control and provide security to the places Britain wants them to return to.

23 Although brought up during the FAC meeting, this point was only brushed upon and the severity of this issue with regards to Britain's policy was simply not considered (Foreign Affairs Committee, 2017, Q121-123). 
Interviews with Rohingya Muslims taking refuge in Cox's Bazar refugee camp were consistent and frequent from the start of Myanmar's campaign on August 25th 2017. In a Channel 4 News documentary, a child named Mohammad Faisal spoke of how he had seen father shot, and a mourning woman told how her three daughters, two sons and husband been burned to death when their home was razed (Rohingya Documentary: "A boy with no name for a people with no identity", 2017, 16:05 and 06:40 respectively). Al Jazeera published an article in October which told of how a woman named Rajuma saw her baby thrown into a fire before she was gang-raped by Burmese soldiers ("Rohingya survivor: The army threw my baby into a fire", 2017). Mass rape and infanticide were common themes described by Rohingya who escaped to Bangladesh, and the violence carried out in Rakhine was undoubtedly gendered.

In the ethnic cleansing of Rohingya, rape was not only used to symbolise the domination of Islam by Buddhism, but also used to ensure the victims do not want to return to Myanmar. Reid-Cunningham has further argued that rape intends to cause psychological harm to not only the women, but also the rest of the community in which they live-damaging the 'purity' of a given community and rendering all members (not just the rape victims themselves) traumatised by the experience (Reid-Cunningham, 2008, p. 281). By utilising systematic rape, Myanmar's military was ensuring the psychological barriers needed to overcome in order for victims to return to Myanmar were as harsh as possible. Communities were torn apart and tainted by the memory of the rape of Rohingya women, which led to thousands of pregnancies conceived through genocidal rape (Beech, 2018). In cases of rape, the babies born are a constant reminder of the ordeal their mothers went through, and are often cast aside by the damaged community (Beech, 2018). As Jonathan Miller stated from Cox's Bazar, the stories told to journalists and aid workers were consistent from every single person landing on the Bangladesh side of the Naf river-stories which told of the mass rape of Rohingya women by the military, and also by locals (Rohingya Documentary: "A boy with no name for a people with no identity", 2017, 06:50). In short, Myanmar's campaign of rape was designed to ensure Rohingya communities did not wish to return, with reminders of Buddhist mass violence and accompanying rape living on in the form of rape-conceived children.

As a result of the trauma and extreme violence Rohingya underwent, humanitarian aid organisations in the refugee camp worked on psychological rehabilitation (Gaynor, 2017). On the one hand, this is shows the success of international organisations, funded by donations such as those from Britain (Foreign Affairs Committee, 2017, Q85). On the other, it highlights another huge issue with Britain's policy of refugee repatriation. The violence described by victims were so consistent and so frequent that the majority of Rohingya were rendered fearful of returning to their ancestral homes. Rohingya in Cox's Bazar, as well as those taking refuge in India an elsewhere, repeatedly told of their fear of returning to Myanmar as a result of psychological trauma. ${ }^{24} \mathrm{~A}$ representative of the UN High Commission for Refugees (UNHCR) told Al Jazeera English of how the "general feeling" in Cox's Bazar was that people feared that they would be returning to a life of persecution, with the added trauma of having had women of Rohingya communities raped and mutilated and many of their friends and family members killed ("Rohingya refugees in Bangladesh fear repatriation to Myanmar", 2017).

24 The hidden genocide (2013); Rohingya Documentary: "A boy with no name for a people with no identity" (2017) show victims voicing such opinions. 
Evidently, getting a million Rohingya to voluntarily return under current conditions would be an impossibility, which was undoubtedly the intention of the Burmese military in their use of mass rape. ${ }^{25}$ In the Foreign Affairs Committee meeting, Field was asked about this issue by Mike Gapes MP, who questioned how anyone could ever return having experienced such atrocities (Foreign Affairs Committee, 2017, Q121). Field had no adequate response to this, saying that he was aware of such a situation but that the goal should be returning Rohingya to the "land of their forefathers" (Foreign Affairs Committee, 2017, Q101). Having survived the violence in August, and having been persecuted for so long, it is not surprising that many Rohingya do not wish to return. In terms of the Rohingya's opinion, then, return would only be an option if the right conditions were created by Burmese authorities, with the oversight of international organisations as desired by Britain. However, Myanmar's attitude was far from compliant, and their track record shows that Britain's hope for this to occur was entirely unrealistic.

\section{CONCLUSION}

The repatriation of Rohingya refugees to Myanmar was not a realistic policy. In order for it to occur, Myanmar would have needed to provide a safe and secure environment, allow international observation and remove its military whilst simultaneously backtracking on decades of state-planned stigmatisation, persecution and isolation. QMUL's excellent research in 2015 showed the application of Feierstein's stages of genocide was possible in this case, and Myanmar followed those stages to the letter until the ethnic cleansing campaign began in August. The likelihood of Myanmar reversing its policy was, and remains, minimal, and the continued denial of the very existence of Rohingya by Burmese authorities added to the issues undermining Britain's policy. Myanmar showed that it did not want the Rohingya to be a part of its nation, and any return 'home' following ethnic cleansing would have be to concentration camps, cut off from Burmese society.

This essay has analysed Britain's policy on two main levels, those being the perspective of Burmese authorities and the position of the Rohingya themselves. The campaign in August 2017 was ethnic cleansing—using extreme violence or, terror-inspired means, to force the ethnoreligious Rohingya group to leave Rakhine state. The frequency of rape in this case links closely to those discussed by Reid-Cunningham in the cases of Yugoslavia and Sudan and add further to the argument that Myanmar's campaign was aimed at preventing the Rohingya's return. This campaign caused unimaginable harm both physically and psychologically to the victims, and when added to the decades-long stripping of human-rights they experienced meant the Rohingya were unlikely to want to return to their ancestral land without unprecedented societal change in Myanmar.

It would be safe to conclude that Britain's approach toward the ethnic cleansing of Rohingya was excessively diplomatic and overly optimistic. However, it would also not be going too far to argue that Britain itself did not believe in the policy it was following. What the FCO did was outline an ideal scenario which Britain wanted to see, rather than develop one which could be workable. When spelling out the UK's policy, Field himself highlighted the question as to what it was the Rohingya would be returning (Foreign Af-

25 One million a result of the combination of 400,000 taking refuge in Bangladesh prior to the August 2017 ethnic cleansing, and the 600,000 forced to flee during it. 
fairs Committee, 2017, 073). Myanmar had made it clear in its actions from the start that Rohingya's ancestral homes would not be returned, with property being looted and (under Burmese law) the land on which homes previously stood being repossessed by the government. Of the three policy options immediately available to Britain, they chose the one which would require the minimum involvement for the UK. Rather than build a policy which would help the Rohingya people, they chose to steer as far away from interference as possible.

Not only was Britain's policy unrealistic, it was knowingly so. The consequences of such an approach could have serious ramifications if either the Rohingya are left to reside in disease-ridden, restrictive, temporary camps or they return to a state which regards them as disposable. Admittedly, the first stage of Britain's policy was achieved with a Myanmar-Bangladesh agreement, with UNHCR's involvement being discussed in negotiations. However, repatriation was clearly a fantasy which even if made reality would result in hundreds of thousands of people living in concentration camps in Myanmar. The homes of the Rohingya no longer exist, and now the only options are refugee camps in Bangladesh, or Myanmar-controlled concentration camps in Myanmar.

Unless the UK could provide a situation where Myanmar reinstates the Rohingya as a minority, allows them rights to work, education and movement, rebuilds razed villages, withdraws security forces who perpetrated the violence and makes efforts to peace-build between minorities, then their policy of refugee repatriation was wholly unrealistic. These will clearly never happen. Even if some Rohingya do return following the Myanmar-Bangladesh agreement, what awaits them in Myanmar is likely to be a continuation of what the ISCl observed in 2015, with genocide a perhaps likely future stage for those Rohingya who remain under Burmese control.

\section{BIBLIOGRAPHY}

Anand, J. P. (1978, July 8). Refugees from Burma. Economic and Politic Weekly, 13(27), 1100-1101.

Army offensive aimed at 'preventing' return of Rohingya. (2017, October 11). Al Jazeera. Retrieved January 10, 2018, from http://www.aljazeera.com/news/2017/10/armyoffensive-aimed-preventing-rohingya-return-171011092607965.html

Asrar, S. (2017a, September 28). How Myanmar expelled the majority of its Rohingya. Al Jazeera. Retrieved January 10, 2018, from http://www.aljazeera.com/indepth/interactive/2017/09/myanmar-expelled-majority-rohingya-170926114753901.html

Asrar, S. (2017b, October 11). Myanmar crisis explained in maps. Al Jazeera. Retrieved February 12, 2018, from http://www.aljazeera.com/indepth/interactive/2017/09/rohingya-crisis-explained-maps-170910140906580.html

Aung, T. T., \& Lee, Y. (2017, November 23). Myanmar, Bangladesh ink Rohingya deal amid concern over military's role. Reuters. Retrieved February 14, 2017, from https:// uk.reuters.com/article/uk-myanmar-rohingya/myanmar-bangladesh-ink-rohingya-returndeal-amid-concern-over-armys-role-idUKKBN1DNOH8

Beech, H. (2018, July 8). When a baby is an everyday reminder of Rohingya horror. New York Times. Retrieved July 11, 2018, from http://www.genocidewatch.com/singlepost/2018/07/08/When-a-Baby-Is-an-Everyday-Reminder-of-Rohingya-Horror 
Bemma, A. (2017, November 25). Rohingya must be consulted before repatriation. Al Jazeera. Retrieved February 10, 2018, from http://www.aljazeera.com/news/2017/11/ rohingya-consulted-repatriation-groups-171125094810411.html

Bray, J. (1992). Ethnic minorities and the future of Burma. The World Today, 48(8/9), 144147.

Definitions: Ethnic cleansing. (n.d.). Retrieved February 12, 2018, from https://www. un.org/en/genocideprevention/ethnic-cleansing.shtml

Definitions: Genocide. (n.d.). Retrieved February 14, 2018, from https://www.un.org/en/ genocideprevention/genocide.shtml

Edroos, F. (2017, September 7). Rohingya warn of another Srebrenica if violence rages. Al Jazeera. Retrieved July 13, 2018, from https://www.aljazeera.com/news/2017/09/ rohingya-warn-srebrenica-violence-rages-170907143650993.html

Feierstein, D. (2014). Genocide as a social practice: Reorganizing society under the Nazis and Argentina's military juntas. New Brunswick, NJ: Rutgers University Press. https:// doi.org/10.26530/OAPEN_625248

Foreign Affairs Committee. (2017, October 25). Oral evidence: Violence in Rakhine State, HC435. Retrieved February 7, 2018, from http://data.parliament.uk/writtenevidence/ committeeevidence.svc/evidencedocument/foreign-affairs-committee/violence-in-rakhine-state/oral/72037.html

Galache, C. S. (2014, September 22). Rohingya and national identities in Burma. AsiaPacific, New Mandala. Retrieved February 13, 2018, from http://www.newmandala.org/ the-rohingya-and-national-identities-in-burma/

Garland, J. (Director, with Gatehouse, G.). (2017, November 24). Our world: The massacre at Tula Toli [BBC World News documentary]. Retrieved December 12, 2017, from http://www.bbc.co.uk/programmes/n3ct2kf2

Gaynor, T. (2017, October 26). Mental health first aid on the frontlines of the Rohingya crisis. Retrieved November 3, 2017, from http://www.unhcr.org/uk/news/ stories/2017/10/59de22951b/mental-health-first-aid-frontlines-rohingya-crisis.html

Green, P., MacManus, T., \& de la Cour Venning, A. (2015). Countdown to annihilation: Genocide in Myanmar. London. Retrieved February 10, 2018, from statecrime.org/ data/2015/10/ISCI-Rohingya-Report-PUBLISHED-VERSION.pdf

Haley, N. (2017, September 28). Remarks at a UN Security Council Briefing on the Situation in Burma. Retrieved February 11, 2018, from https://usun.state.gov/remarks/7998

The hidden genocide. (2013, October 30). [Al Jazeera English]. Retrieved February 14, 2018, from https://www.youtube.com/watch?v=dSkZlgk76-E\&t=3s

Hindawi, S., Kishk, A., \& Grace, H. (2017, August 9). The Rohingya: Silent abuse [Al Jazeera World documentary]. Retrieved February 7, 2018, from http://www.aljazeera.com/ programmes/aljazeeraworld/2017/07/rohingya-silent-abuse-170730120336898.html

Holmes, O. (2017, September 19). Myanmar: Satellite imagery confirms village of Tula Toli razed. The Guardian. Retrieved February 12, 2018, from https://www.theguardian. com/world/2017/sep/19/myanmar-satellite-imagery-confirms-rohingya-village-of-tulatoli-razed

House of Commons Foreign Affairs Committee. (2017, December 6). Violence in Rakhine State and the UK's response: First Report of Session 2017-19. Retrieved February 7, 2018, from https://publications.parliament.uk/pa/cm201719/cmselect/cmfaff/435/435. pdf

Ibrahim, A. (2018). The Rohingyas: Inside Myanmar's genocide. Glasgow: Hurst. 
Khalid, S. (2017, September 12). Rohingya in India fear deportation to Myanmar. Al Jazeera. Retrieved February 12, 2018, from http://www.aljazeera.com/indepth/features/2017/09/rohingya-india-fear-deportation-myanmar-170911134706072.html

Lewis, S. (2017, September 27). Government will take over burned Myanmar land-minister. Reuters. Retrieved February 14, 2018, from https://uk.reuters.com/article/ uk-myanmar-rohingya/government-will-take-over-burned-myanmar-land-minister-idUKKCN1C200S

Mackinnon, C. A. (2005). Genocide's sexuality. Nomos, 46 (Political Exclusion and Domination), 313-356.

Massacre in Myanmar: A Reuters special report. (2018, February 8). Reuters. Retrieved February 8, 2018, from https://www.reuters.com/investigates/special-report/myanmarrakhine-events/

McGowan, W. (1993). Burmese Hell. World Policy Journal, 10(2), 47-56. www.jstor.org/ stable/40209305

Myanmar: Are crimes against humanity taking place? (2017, March 10). [Newsnight]. Retrieved February 10, 2018, from https://www.youtube.com/watch?v=pebrk29ZJW8\&t=1s

Myanmar: Rohingya returns unthinkable until apartheid structure is dismantled. (2017, November 23). Retrieved July 13, 2018, from https://www.amnesty.org/en/latest/ news/2017/11/myanmar-rohingya-returns-unthinkable-until-apartheid-system-is-dismantled/

Myanmar: Rohingya trapped in dehumanising apartheid regime. (2017, November 21). Retrieved February 14, 2018, from https://www.amnesty.org/en/latest/news/2017/11/ myanmar-rohingya-trapped-in-dehumanising-apartheid-regime/

Myanmar: Scorched-earth campaign fuels ethnic cleansing of Rohingya from Rakhine state. (2017, September 14). Retrieved February 12, 2018, from https://www.amnesty. org/en/latest/news/2017/09/myanmar-scorched-earth-campaign-fuels-ethnic-cleansingof-rohingya-from-rakhine-state/

Myanmar: Suu Kyi's first national speech on crisis. (2017, September 19). [Al Jazeera English]. Retrieved February 14, 2018, from https://www.youtube.com/watch?v=eHV6_ BOrKeA

Reid-Cunningham, A. R. (2008). Rape as a weapon of genocide. Genocide Studies and Prevention: An International Journal, 3(3), 279-296. https://doi.org/10.1353/ gsp.2011.0043

Rohingya crisis: Suu Kyi says 'fake news helping terrorists'. (2017, September 6). BBC News. Retrieved February 12, 2018, from http://www.bbc.co.uk/news/worldasia-41170570

Rohingya Documentary: "A boy with no name for a people with no identity". (2017, September 18). [Channel 4 News]. Retrieved February 5, 2018, from https://www.youtube.com/watch?v=-TezCbjmruM

Rohingya refugees in Bangladesh fear repatriation to Myanmar. (2017, November 4). [Al Jazeera English]. Retrieved February 10, 2018, from https://www.youtube.com/ watch?v=rwuo-4KKqJY

Rohingya survivor: The army threw my baby into a fire. (2017, October 13). Al Jazeera. Retrieved January 20, 2018, from http://www.aljazeera.com/news/2017/10/rohingyasurvivor-army-threw-baby-fire-171013083525896.html

Ruma, P. (2017, November 25). Bangladesh says agreed with Myanmar for UNHCR to assist Rohingya's return. Reuters. Retrieved July 18, 2018, from https://www.reuters. 
com/article/us-myanmar-rohingya/bangladesh-says-agreed-with-myanmar-for-unhcr-toassist-rohingyas-return-idUSKBN1DP05N

Safi, M. (2017, September 6). Aung San Suu Kyi claims 'terrorists' are misinforming world about Myanmar violence. The Guardian. Retrieved February 12, 2018, from https:// www.theguardian.com/world/2017/sep/06/aung-san-suu-kyi-blames-terrorists-for-misinformation-about-myanmar-violence

Sloan, A. (2017, February 17). Britain rejecting child refugees is no surprise. Al Jazeera. Retrieved July 11, 2018, from https://www.aljazeera.com/indepth/opinion/2017/02/ britain-rejecting-child-refugees-surprise-170214081706478.html

Ther, P. (2016). The dark side of Nation States: Ethnic cleansing in modern Europe (C. Kreutzmüller, Trans.). New York, NY: Berghahn Books.

Thousands of Rohingya flee Myanmar for Bangladesh. (2017, August 24). Al Jazeera and new agencies. Retrieved December 10, 2017, from http://www.aljazeera.com/ news/2017/08/thousands-rohingya-flee-myanmar-bangladesh-170823193439077.html

UN human rights chief points to 'textbook example of ethnic cleansing' in Myanmar. (2017, September, 11). UN News Centre. Retrieved February 5, 2018, from http:// www.un.org/apps/news/story.asp?NewsID=57490\#.WnsUIJPvB24

United Nations Human Rights Office of the High Commissioner. (2017, October 11). Brutal attacks on Rohingya meant to make their return almost impossible-UN human rights report. Retrieved February 12, 2018, from http://www.ohchr.org/EN/NewsEvents/Pages/DisplayNews.aspx?NewsID=22221\&LangID=E

United Nations International Criminal Tribunal for the Former Yugoslavia. (2004, April 19). Prosecutor v. Radislav Kristic: Appeals Chamber Judgement. Retrieved July 3, 2018, from http://www.icty.org/x/cases/krstic/acjug/en/krs-aj040419e.pdf

Winkler, C. (1991). Rape as social murder. Anthropology Today, 7(3), 12-14.

Zarni, M., \& Cowley, A. (2014). The slow-burning genocide of Myanmar's Rohingya. Pacific Rim Law \& Policy Journal Association, 23(3), 681-752. 